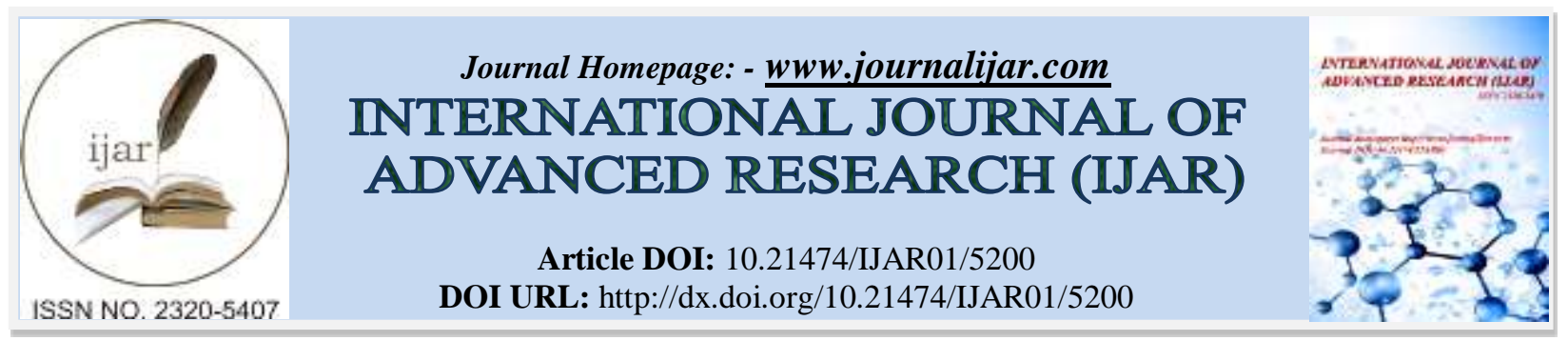

RESEARCH ARTICLE

\title{
BUSINESS MODEL OF AMAZON INDIA - A CASE STUDY.
}

Dr. Bharti Wadhwa and Dr. Anubha Vashisht, Ms. Davinder Kaur

Symbiosis Centre for Management Studies, NOIDA, Symbiosis International University, Pune.

\section{Manuscript Info}

(..........................

Manuscript History

Received: 17 June 2017

Final Accepted: 19 July 2017

Published: August 2017

Key words:-

Entry and expansion strategy, Amazon, strategy, Customer services, Alibaba, China, India, Business Model, Chai Cart.

\section{Abstract}

Amazon is an American international e-commerce company. It was started by Jeffrey P. Bezos in the year 1994. And it was launched in India in June 2013. Three years back, Amazon had no infrastructure in India, and now it dominates the Indian markets. At the very start it was perception of investors that in India It will not go long like China as in the year 2004 when Amazon entered in China it hasn't seen much success there with Alibaba, its Chinese competitor, dominating the ecommerce market. After its bad run in China, Bezos is going all in for India.

Fact behind formation of Amazon in India was its huge number of headcounts i.e. 1.25 billion four times as big as the U.S.'s and more than doubles Europe's. Of these, 500 million, around 35 percent, are internet users. As per researches the yearly growth rate of internet users is highest in India around six million users join every month. Researchers expect the online shopping market in India to reach \$15 billion by 2016 up from only $\$ 35$ million in 2014 .

Copy Right, IJAR, 2017,. All rights reserved.

\section{Introduction:-}

Amazon is an American international e-commerce company. It was started by Jeffrey P. Bezos in the year 1994. And it was launched in India in June 2013.Three years back, Amazon had no infrastructure in India, and now it dominates the Indian markets. At the very start it was perception of investors that in India It will not go long like China as in the year 2004 when Amazon entered in China it hasn't seen much success there with Alibaba, its Chinese competitor, dominating the e-commerce market. After its bad run in China, Bezos is going all in for India.

Fact behind formation of Amazon in India was its huge number of headcounts i.e. 1.25 billion four times as big as the U.S.'s and more than doubles Europe's. Of these, 500 million, around 35 percent, are internet users. As per researches the yearly growth rate of internet users is highest in India around six million users join every month. Researchers expect the online shopping market in India to reach $\$ 15$ billion by 2016 up from only $\$ 35$ million in 2014.

Platform-based markets have become increasingly prevalent, and comprise a large and rapidly growing share of today's economy (e.g., Eisenmann 2007). Such markets are often described as multi-sided because multiple groups of participants - such as consumers and complementors - need to gain access to the same platform to interact with each other, and a platform's success depends on its ability to bring them on board (e.g., Rochet and Tirole2003; Parker and Van Alstyne 2005).

Corresponding Author:- Dr. Bharti Wadhwa.

Address:- Symbiosis Centre for Management Studies, NOIDA, Symbiosis International University 
This makes India a very important market for internet giants. India will overtake China as the world's most populous country in just seven years, according to the UN. It is now the world's fastest-growing major economy, and the IMF projects $7.5 \%$ growth next year. Online retail spending data of Indians are shown in Figure 1.

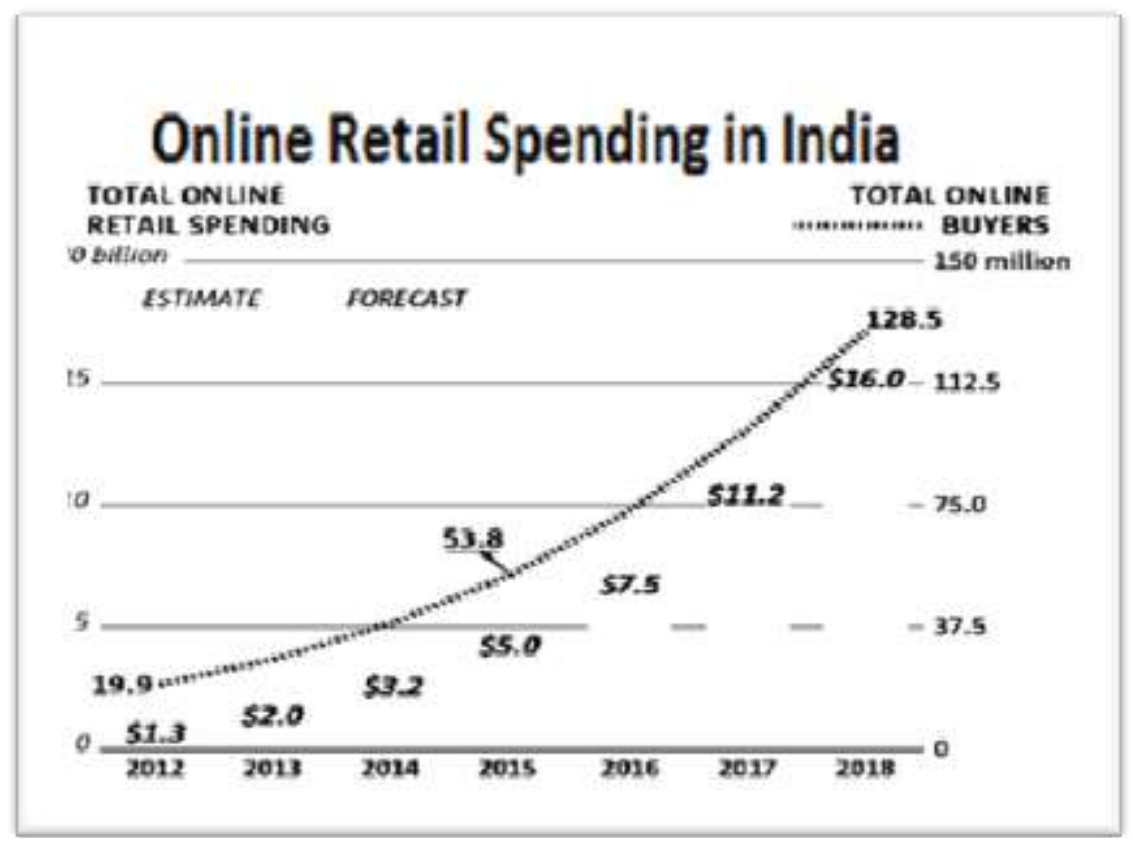

Source: Forester Research online, Retail Forecast, 2013-2018, Asia Pacific

They just required an innovative business model, beginning with finding products to sell in India though, with FDI restrictions in Retail, Amazon launched Junglee.com though the website did not allow any transaction on the site, and it helped Amazon get an insight into the e-commerce space in India as well as to build brand loyalty. Amazon opted marketplace model. Market place model provides small businesses a huge scaling opportunity without having to build the technical or operational infrastructure of scale. For example small business seller or dresses in Rajasthan, currently their reach is very constrained and growth is much limited. But by participating in these market places, this small business can now reach all over India. All the marketplaces have specific services for sellers that define onboarding, verification, tools to provide insights and fulfillment services. For example, Amazon has Vendor services to make it very easy for a vendor to bring their warehouses online. Apart from all these Amazon provides studio services that support the vendor to photograph all the products and make them ready for online selling. Through the whole life of the relationship for example, these market places provide inventory reports, order reports and trends. The vendors need to focus on their products and find easy ways to ship their products to the Warehouses of the Marketplace.

India's growth potential in e-commerce industry is growing and changes can be seen over a year. The sector in India has grown by 34\% (CAGR) since 2009 to touch 16.4 billion USD in 2014 (Internet and Mobile Association of India (IAMAI), CRISIL, Gartner, PwC analysis and industry experts). The sector is expected to be in the range of 22 billion USD in 2015.

D.k.gangeshwar. (2013)," e-commerce or internet marketing: a business review from Indian context", international journal of $\mathrm{u}$ - and e- service, science and technology concluded that the e-commerce has a very bright future in India although security, privacy and dependency on technology are some of the challenges for e-commerce. Some researchers also found some challenges for ecommerce businesses in India. Miyazaki and Fernandez (2001) suggested in their study that the technology acceptance model should be applied to electronic commerce research with caution. In order to develop a successful and profitable web shop, understanding customers' needs is essential. It has to be ensured that products are as cheap in a web shop as purchased from traditional channels. 


\section{Objectives:-}

- Assess the issues and challenges of running Amazon in India

- To study amazon business models to overcome these challenges and become the leading ecommerce company in India.

- To study expansion strategy of Amazon in India

\section{Challenges:-}

Amazon has consumer market in United States but it is a growing online consumer market in India having different challenges. The first and foremost challenge in India faced by the amazon was restrictions on foreign companies using e-commerce to sell their products directly to the Indian consumer. The Indian government, however, plans to allow foreign companies that manufacture their products in the country to sell them directly to consumers over the Internet. But Amazon would have to start making its products in India to take advantage of the change in the law. Another difficulty that Amazon India faced was the limited infrastructure available to get the goods to consumers. In India, less than $12 \%$ of people uses plastic cards i.e. credit or debit cards, so Amazon has had to adapt to a "Cash on Delivery" model, which isn't yet available in all the areas. There is no shortage of goods produced by Indians, but most vendors in the country are small. Three years ago, relatively few retailers there sold their products online because they believed e-commerce to be too complex and time consuming. And India's cash economy did not facilitate online transactions.

\section{Amazon India Business Models:-}

Ecommerce business model generally consists of eight key components i.e. value proposition, market opportunity, revenue model, competitive environment, competitive advantage, market strategy, organizational development, and management team (Ghosh, 1998).

Value proposition specify how product and service are put together and extended to fulfil customer needs by company (Kambil et al., 1996). For attracting the customer Amazon India is doing a lot for this it has enlisted momand-pop store owners as partners in its delivery platform. In small villages and remote areas where few people have internet access, residents can go to their local store and use the owner's internet connection to browse and select goods from online Store. Store owners record their orders, alert customers when their products are delivered to the store, collect the cash payment, and pass along the money - minus a handling fee to Amazon. And store owners report increased sales of their own while customers are on-site.

Amazon targets the middle class \& upper class people who have hands on experience in technology but don't have much time to do shopping from the physical outlets. Taking this into consideration Amazon has successfully positioned itself as a Glocal (Go global Act local) e-commerce giant where one can buy anything \& get it delivered at any remote locations. Using the catchphrase Aur Dikhao in its most recent campaign in India, it has further helped them carve a distinct space in the consumer's mind.

Company acquired many IT \& e-commerce start-ups like pets.com, audible.com, Junglee.com, IMBD.com, Zappos.com, Woot etc. for providing high value to their customers using existing technology of the acquired partners at low cost.

Company's CRM records data on customer's buying behavior. It enables them to offer individual items, related items or bundle them as an offer, based upon preferences demonstrated through purchases or items visited. 

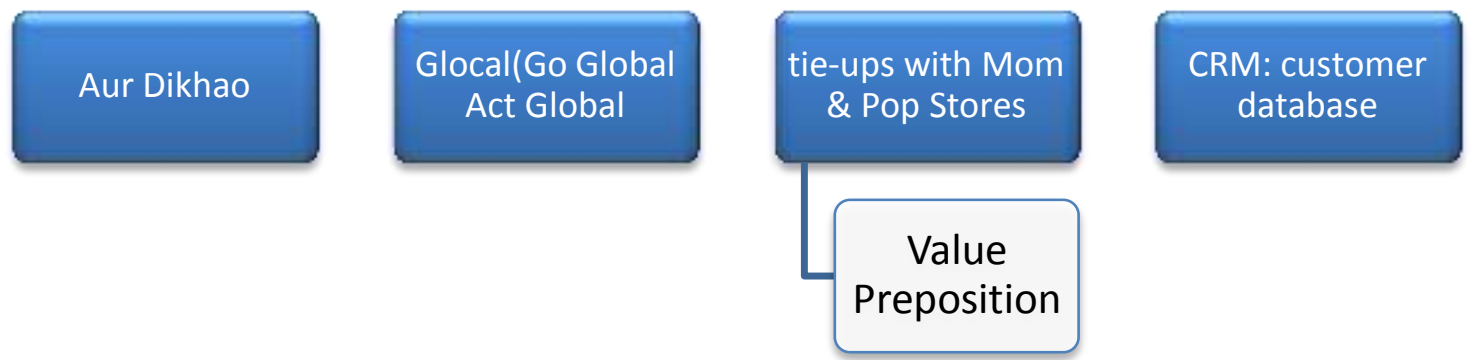

Figure 2:- showing ecommerce business models

Revenue model defines how a firm aims to generate higher return on investment and profits. Important e-commerce revenue models include advertising, subscription, transaction fee, sales, and affiliate revenue models (Laudon and Traver, 2009). Market opportunity gives description of possible revenue a company is likely to generate from its proposed marketspace.

Amazon's strategy involves discounts, low prices and wide range of products sold via direct selling or marketplace. In the U.S., by contrast, Amazon holds and sells its own inventory of toys, books, and more in addition to selling goods from third-party sellers. The Indian Government, however, plans to allow foreign companies that manufacture their products in the country to sell them directly to consumers over the Internet. But Amazon would have to start making its products in India to take advantage of the change in the law. Amazon's model in India differs slightly from the business model in United States. As we discussed earlier that Indian government doesn't allow companies with major foreign ownership to operate retail locations having their own inventory. Because of this, Amazon serves as a middle man between sellers and buyers, and doesn't sell any inventory of its own. But, Amazon helps sellers with warehousing and shipping goods.In the U.S., by contrast, Amazon holds and sells its own inventory of toys, books, and more in addition to selling goods from third-party sellers.

Competitive environment pertains to rival companies operating in same market space, potential new entrants in the market, product substitutes available in the market and bargaining power of customers and suppliers over your business (Porter, 1979).

Market strategy is the program company designs to outline how it will get into the market and draw in customers (Laudon and Traver, 2009).

Organizational development strikes a balance between all the functions and skills necessary to carry out each job in a company, which require timely recruitment of suitable candidates. Management team comprises employees at the highest level of company who determine growth and expansion Amazon has the same business model considering all key components.

\section{How Amazon Model Works:-}

First of all, Portals shows the Sellers List who sell the desired portfolio products and then get customers browsing through those products. After matching seller and customers it creates appealing discounts after that Customer Shops for the desired products and then Seller ships the product to customer. If Product Accepted and Not returned back then Seller gets his agreed price of the product minus the commission charged by Amazon for doing everything 
they do. Thus the core bread and butter of the Model is "X\% commission on the total sale value given to the seller". This model has been shown by the Figure 3.

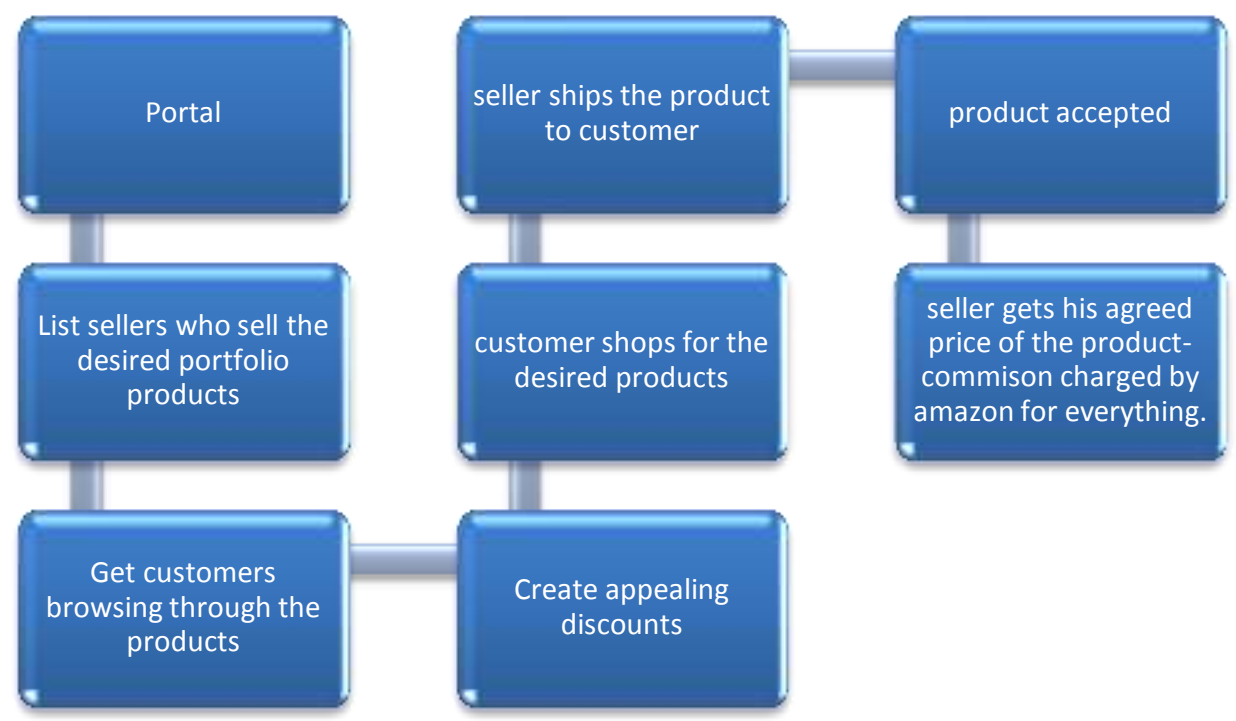

Figure 3:- showing workings of Amazon model

\section{Strategies for Sellers:-}

Amazon moved out a program "Amazon Chai Cart" these are the mobile tea carts that navigated city streets, serving refreshments to small-business owners and teach them the benefits of e-commerce. The Chai Cart team reportedly traveled more than 9,400 miles across 31 cities and engaged with more than 10,000 sellers.

Other move that Amazon created was Amazon Tatkal, a self-described "studio on wheels" that provides a suite of launch services, such as registration, imaging, cataloging, and sales training so far it has been covered in 15 cities. Tatkal enables Small and Medium Businesses (SMBs) to get online and sell on Amazon.in, in less than 60 minutes. Starting with New Delhi, Amazon Tatkal will traverse the country, engaging with thousands of entrepreneurs, artisans, manufacturers and sellers and help them sell online on the spot.

Amazon.in has five crore products from 75,000 sellers. The number of sellers has witnessed a 250 percent growth annually in 2015 and as per the officials of Amazon this launch would help thousands of small and medium businesses in India.

The company also introduced "Easy Ship and Seller Flex" With easy ship Amazon couriers pick up packaged goods from a seller's place of business and deliver them to consumers. And with the seller flex, vendors registered under Amazon designate a section of their own warehouses for products to be sold on the website, and Amazon coordinates the delivery logistics. This "neighborhood" approach is convenient for sellers and has benefited Amazon by speeding up delivery of some products.

Amazon also had to adapt delivery and fulfillment. In the U.S., Amazon uses a centralized shipping platform, which it calls Fulfillment by Amazon (FBA), to store and distribute the products it sells. Sellers send their goods to Amazon's fulfillment centers and pay a fee for the corporation to store, pick, pack, and ship their wares. Amazon implemented FBA in India as well, and to date has built nearly two dozen warehouses there, the largest one in Kothur in Telangana. 


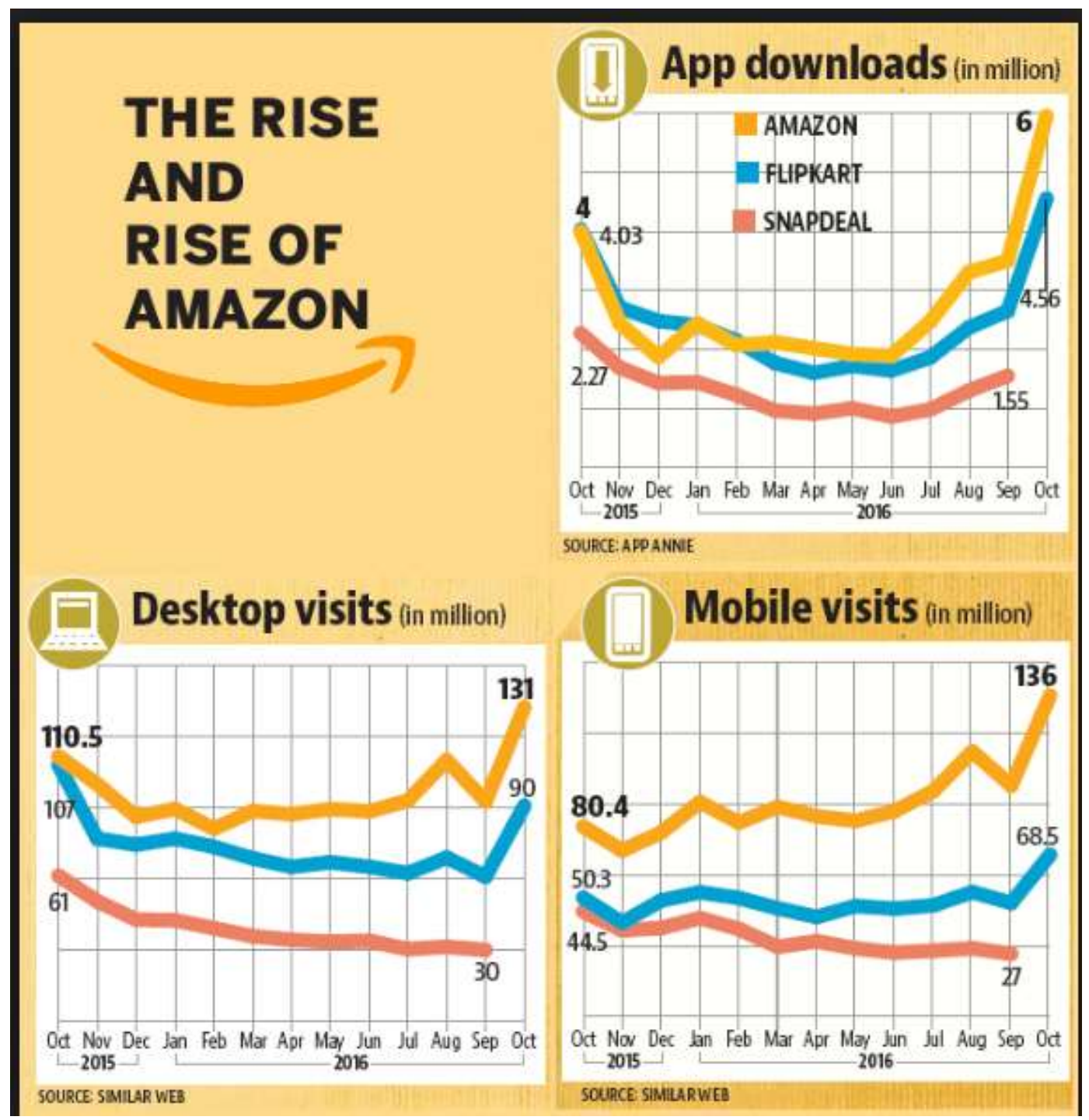

Figure 4:- showing the growth of Amazon India

After reading a report that in future web commerce will grow upto 2300\%, Jeff Bezos selected about top 20 products to sell them online. After that he narrowed these products to 5 books, videos, computer software, hardware, and compact discs and then at last selected Books. This is result of good planning and innovative thinking. The result was just achieved in the first two month with sales rise up to $\$ 20,000 /$ week.

Amazon is the only major player to increase its market share from 14 to 21 percent. It is consistently eating up Flipkart and Snapdeal's share, and the $\$ 3$ billion investment will certainly help.

Overall, Amazon only saw tepid 3\% international sales growth this quarter, though the company said that would have been $12 \%$ if it weren't for the unfavorable foreign exchange impact. Still, even $12 \%$ is down from $14 \%$ quarterly growth in Q2 2014, and 20\% in 2013 (those figures also exclude the effect of exchange rates).

In India, he faces a set of challenges unique to the country. For example, it's incredibly mobile-first - the director of Google India predicts that by $2017,70 \%-80 \%$ online transactions will happen via smartphone. Plus, The AP reported in August 2014 that fewer than 12\% of Indians had credit or debit cards, so Amazon has had to adapt to a "Cash on Delivery" model, which isn't yet available in all areas. 


\section{Amazon - A road ahead:-}

Amazon started with bookstores, which soon converted to the top online retailer across the world, and currently, even though it has a lot of competition, Amazon has a strong base of customers who buy from the online retailer.

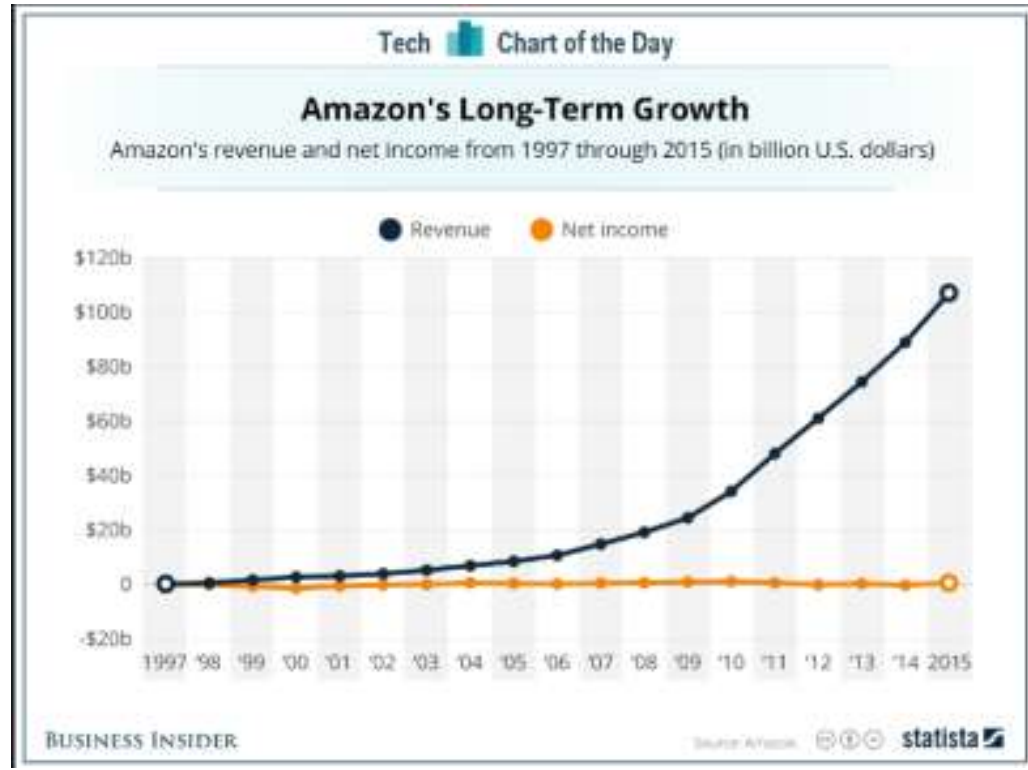

\section{Conclusion:-}

Figure 5:- showing the Revenues of Amazon India

Amazon is an American international e-commerce company. It was started by Jeffrey P. Bezos in the year 1994. And it was launched in India in June 2013. Three years back, Amazon had no infrastructure in India, and now it dominates the Indian markets. So main objective of the case is to study the challenges faced by Amazon India during initial years and what strategy it followed to overcome the challenges. This case will also study the Business Models of Amazon India.

At the very start it was perception of investors that in India It will not go long like China as in the year 2004 when Amazon entered in China it hasn't seen much success there with Alibaba, its Chinese competitor, dominating the ecommerce market. After its bad run in China, Bezos is going all in for India.

Fact behind formation of Amazon in India was its huge number of headcounts i.e. 1.25 billion four times as big as the U.S.'s and more than doubles Europe's. Of these, 500 million, around 35 percent, are internet users. As per researches the yearly growth rate of internet users is highest in India around six million users join every month. Researchers expect the online shopping market in India to reach $\$ 15$ billion by 2016 up from only $\$ 35$ million in 2014.

Amazon is known for knowledgeable products. Amazon in India work on complex business challenges to innovate and create efficient solutions that enable various Amazon businesses, including Amazon websites across the world as well as support Payments, Transportation, and Digital products and services like the Kindle family of tablets, ereaders and the store. Reasons of its success are the finest talent and strong leaders with proven experience working to make Amazon the Earth's most customer-centric company. Apart from this Technological innovation drives the growth of Amazon, offering customers more selection, convenient shopping, and low prices

\section{References:-}

1. Cennamo, Carmelo, Juan Santalo. 2013. Platform competition: Strategic trade-offs in platform markets. Strategic Management Journal 34(11) 1331-1350.

2. Eisenmann, Thomas R., Geoffrey Parker, Marshall W. Van Alstyne. 2011. Platform envelopment. Strategic Management Journal 32(12) 1270-1285.

3. E-Commerce or Internet Marketing: A Business Review from Indian Context", International Journal of u- and e- Service, Science and Technology by D.K.Gangeshwar. (2013) 
4. Miyazaki A.D. and Fernandez A. (2001), Consumer perceptions of privacy and security risks for online shopping, The Journal of Consumer Affairs, 35(1), pp 27-44.

5. Rochet, Jean-Charles, Jean Tirole. 2003. Platform competition in two-sided markets. Journal of European Economic Association 1(4) 990-1029.

6. Samadi M. and Yaghoob-Nejadi A. (2009), A Survey of the Effect of Consumers' Perceived Risk on Purchase Intention in E-Shopping, Business Intelligence Journal -2(2), pp 261-275.

7. https://hbr.org/2016/07/how-amazon-adapted-its-business-model-to-india

8. https://m.yourstory.com/2016/06/jeff-bezos-amazon-india-china/

9. http://www.businessinsider.in/Amazons-next-big-challenge-Winning-India/articleshow/48210306.cms

10. http://fortune.com/amazon-india-jeff-bezos/

11. https://psaddons.wordpress.com/2015/05/08/amazon-case-study-why-it-is-no-1-in-ecommerce/

12. http://www.icmrindia.org/casestudies/catalogue/Business\%20Strategy/BSTR466.htm

13. https://www.quora.com/How-Amazon-adapted-its-business-model-to-India

14. http://www.businessinsider.in/One-Of-Amazons-Biggest-Challenges-For-The-NewYear/articleshow/45983785.cms

15. http://www.foxnews.com/tech/2014/08/07/amazon-sees-potential-in-india-but-faces-big-challenges.html

16. http://fortune.com/2016/04/08/amazon-regulatory-hurdles-india/

17. http://www.bgr.in/news/amazon-india-launches-tatkal-studio-on-wheels-to-help-people-sell-products-online/

18. https://www.amazon.in/b?ie=UTF8\&node $=8520698031$

19. http://tech.economictimes.indiatimes.com/news/internet/amazons-studio-on-wheels-service-tatkal-to-helppeople-sell-products-online/51429341

20. http://www.marketing91.com/swot-analysis-of-amazon/

21. http://www.thehindu.com/business/Industry/amazon-launches-tatkal-initiative-for-small-and-mediumbiz/article8248760.ece

22. http://www.business-standard.com/article/companies/amazon-tatkal-to-help-smbs-sell-products-online116052400915_1.html

23. https://www.myhomegadgets.com/2016/03/17/14714/

24. http://gadgets.ndtv.com/internet/news/amazon-flipkart-launch-studio-on-wheels-services-for-sellers-803885

25. https://www.myhomegadgets.com/2015/12/25/amazon-india-emerges-as-the-largest-e-commerce-platform-inindia/

26. https://www.myhomegadgets.com/2016/07/29/amazons-already-large-distribution-empire-keeps-expanding/

27. https://www.myhomegadgets.com/2015/11/27/amazon-was-the-most-visited-e-commerce-site-in-india-inoctober-comscore/

28. http://www.marketing91.com/marketing-strategy-of-amazon/

29. http://www.livemint.com/Companies/LCRxzVfXcMi8XjpW2yxFTM/Amazon-Flipkart-and-their-quest-tocontrol-Indias-ecommer.html 